\title{
Pengaruh Waktu Post-Treatment terhadap Sifat Permukaan Lapisan Nitridasi
}

\author{
Wahyu Anhar $^{1 *}$, Syaeful Akbar ${ }^{2}$, Totok Sulistyo ${ }^{3}$, Suprapto ${ }^{4}$ \\ ${ }^{1,2}$ Jurusan Teknik Mesin, Politeknik Negeri Balikpapan \\ ${ }^{3}$ Jurusan Teknik Sipil, Politeknik Negeri Balikpapan \\ ${ }^{4}$ Pusat Sains dan Teknologi Akselerator, BATAN Yogyakarta \\ *email:wahyu.anhar@poltekba.ac.id
}

\begin{abstract}
Post-treatment process on nitridation layer is anadvance treatment process after deposition of nitridation layer on substrate. The characteristic of nitridation layer is effected by post-treatment process. Deposition of nitridation is used by nitrogen gas, with pressure 1.6 mbar, and temperature $300{ }^{\circ} \mathrm{C}$. Furthermore, post-treatment process parameter is used by argon gas, with pressure $1 \mathrm{mbar}$, and temperature $300^{\circ} \mathrm{C}$. Variation times of post-treatment are used by 10, 20, and 30 minutes. The characterization of nitridation layer is known of effect post-treatment time on hardness of nitridation layer. Vickers microhardness tester is used to determine hardness of nitridation layers.
\end{abstract}

Keywords: nitridation layer, post-treatment time, hardness

\begin{abstract}
Abstrak
Proses post-treatmentterhadap lapisan nitridasi adalah proses treatment lanjutan yang dilakukan setelah proses pembentukan lapisan nitridasi.pada permukaan substrat. Karakteristiklapisan nitridasi dapat dipengaruhi oleh proses post-treatment. Pembentukan lapisan nitridasi menggunakan gas nitrogen, dengan tekanan 1,6 mbar, temperatur 300 ${ }^{\circ} \mathrm{C}$, dan waktu $4 \mathrm{jam}$. Sedangkan parameter proses post-treatment dilakukan menggunakan gas argon, tekanan 1 mbar, dan temperatur $300{ }^{\circ} \mathrm{C}$. Variasi waktu post-treatment adalah 10,20 , dan 30 menit. Karakterisasi yang dilakukan terhadap lapisan nitridasi adalah mengetahui angka kekerasan lapisan nitridasi akibat pengaruh waktuposttreatment.Pengujian mikro Vickers digunakan untuk mengetahui angka kekerasan lapisan nitridasi.
\end{abstract}

Kata kunci: lapisan nitridasi, waktu post-treatment, angka kekerasan

\section{Pendahuluan}

Proses post-treatment lapisan nitridasi adalah proses treatment lanjutan yang dilakukan setelah proses pembentukan lapisan nitridasi pada permukaan substrat. Lapisan nitridasi pada permukaan substrat mampu meningkatkan sifat permukaan yaitu kekerasan, dan ketahanan aus [1]. Selain itu, lapisan nitridasi juga merupakan lapisan biokompatibilitas dengan menghasilkan ketahanan korosi yang baik [2].

Karakteristik lapisan nitridasi masih mampu untuk ditingkatkan melalui proses post-treatment. Proses post-treatmentyang dilakukan terhadap suatu lapisan tipis mampu mempengaruhi sifat-sifat lapisan tipis di permukaan substrat [3]-[6].

Oleh karena itu perlu dilakukan penelitian pendahuluan untuk mengetahui pengaruh proses post-treatment terhadap lapisan nitridasi pada permukaan substrat, khususnya pengaruh waktu post-treatment.

\section{Metoda Penelitian}

\subsection{Bahan}

Bahan yang digunakan sebagai substrat (benda uji) adalah cuplikan komponen thrust washer differential. Bentuk komponen thrust washer differential seperti ditunjukkan dalam Gambar 1. 
Bahan untuk membentuk lapisan nitridasi menggunakan gas nitrogen, sedangkan gas yang digunakan dalam posttreatment adalah gas argon.

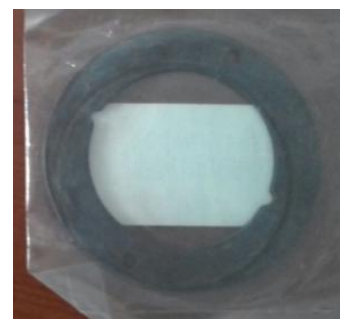

Gambar 1. Komponen thrust washer differential

\subsection{Persiapan Benda Uji}

Benda uji dilakukan pemolesan terlebih dahulu sebelum dilakukan pelapisan nitridasi. Pemolesan menggunakan kertas amplas denganurutan kekasaran dari 200, 400, 600, 800, 1000, 1500, hingga 2000. Untuk lebih memaksimalkan hasil pemolesan, benda uji dipoles kembali menggunakan metal polish, dan alkohol 96\%menggunakan kain beludru. Untuk memudahkan proses pemolesan maka cuplikan benda uji dibuatkan pemegang dari resin. Setelah selesai proses pemolesan maka benda uji dikeluarkan dari pemegangnya.

Benda uji yang telah selesai dipoles, sebelum masuk ke dalam reaktor plasma dicuci terlebih dahulu menggunakan alat ultrasonic cleaner. Proses pencucian menggunakan cairan berupa alkohol 96\%. Benda uji yang telah selesai dicuci selanjutnya dilakukan proses pengeringan.

\subsection{Pelapisan dan Post-Treatment}

Pelapisan nitridasi menggunakan alat plasma nitridasi milik PSTA-BATAN Yogyakarta. Parameter pelapisan nitridasi menggunakan tekanan 1,6 mbar, temperatur $300{ }^{\circ} \mathrm{C}$, dan waktu 4 jam.

Benda uji yang telah dilakukan pelapisan nitridasi selanjutnya dilakukan proses posttreatment. Parameter post treatment menggunakan tekanan 1 mbar, dan temperatur $300{ }^{\circ} \mathrm{C}$ dengan variasi waktu post-treatment 10, 20, dan 30menit.
Gambar 2 menunjukkan alat plasma nitridasi. Di dalam pembentukan lapisan nitrida maka gas yang digunakan sebagai bahan pelapis adalah gas nitrogen, sedangkan dalam post-treatment gas yang digunakan pada alat plasma diganti menjadi gas argon. Penggunaan gas argon (gas mulia) dalam proses post-treatment adalah agar gas posttreatment tidak ikut terdeposisi pada lapisan nitridasi yang telah terbentuk (tidak terbentuk multi layers).

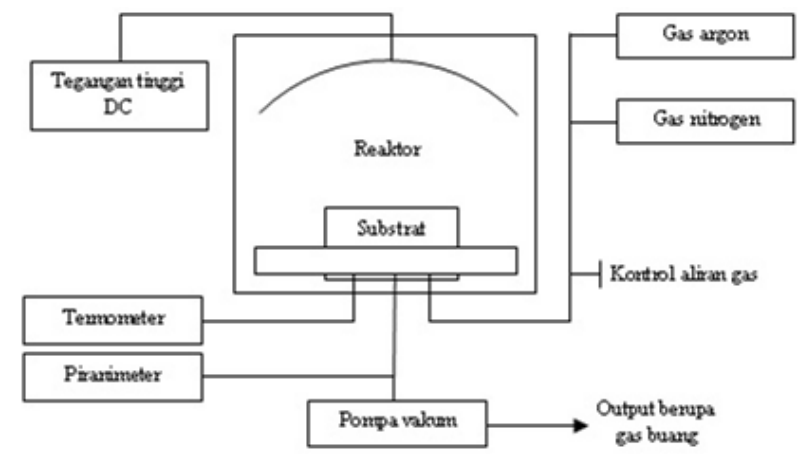

Gambar 2. Skema alat plasma nitridasi

\subsection{Pengujian Kekerasan}

Pengujian kekerasan dilakukan terhadap benda uji yang telah dilapisi gas nitrogen, dan benda uji yang telah dilapisi gas nitrogen yang dilanjutkan dengan post-treatment menggunakan gas argon. Pengujian kekerasan menggunakan metode mikro Vickers dengan alat Matsuzawadigital micro hardness tester MMT-X7 milik PSTA-BATAN Yogyakarta. Satuan yang digunakan untuk menunjukkan angka kekerasan adalah Vickers Hard Number (VHN).

\section{Hasil Penelitian}

Gambar 3 menunjukkan hasil pengujian angka kekerasan pada lapisan nitridasi. Substrat yang telah diberikan pelapisan nitridasi memiliki kekerasan sebesar 145 VHN. Proses post-treatment dengan menggunakan gas argon yang dilakukan terhadap lapisan nitridasi mampu mempengaruhi angka kekerasan lapisan. Telihat bahwa terjadi kenaikan angka kekerasan pada lapisan nitridasi. Post- 
treatment yang dilakukan selama 30 menit, menyebabkan angka kekerasan naik sebesar 169,2 VHN dari 145 VHN.

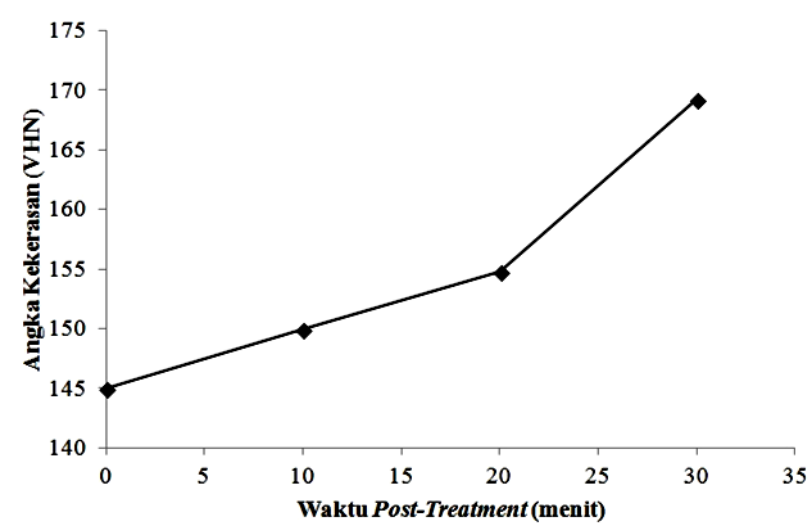

Gambar 3. Pengaruh waktu post-treatment terhadap angka kekerasan lapisan nitridasi

Kenaikan angka kekerasan dalam proses post-treatment adalah diakibatkan adanya benturan-benturan oleh gas argon yang digunakan dalam proses post-treatment. Fenomena ini menyerupai dengan proses shotpeening. Gas argon akan membentur permukaan lapisan nitridasi sehingga terjadi peningkatan kerapatan antar butiran lapisan (compressive stress). Terjadinya peluang peningkatan kerapatan butiran lapisan dikarenakan butiran lapisan yang terbentuk dipermukaan substrat belum rapat. Peningkatan kerapatan antar butiran lapisan menyebabkan peningkatan angka kekerasan. Seiring dengan penambahan waktu posttreatment maka jumlah gas argon yang membentur permukaan lapisan nitridasi makin lama, dan banyak.

Apabila merujuk pada fenomena shot peening yang bertujuan untuk meningkatkan ketahanan fatik [7]-[10] maka angka kekerasan yang ditunjukkan dalam Gambar 3 seharusnya mendapatkan titik optimasi karena kondisi lapisan telah mencapai titik jenuh [9]. Perlu dilakukan penelitian lanjut yakni penambahan waktu post-treatment sehingga mendapatkan titik optimasi angka kekerasan.

\section{Kesimpulan}

Proses post-treatment yang dilakukan pada lapisan nitridasi mampu mempengaruhi karakteristiknya. Salah satu karakteristik yang dipengaruhi adalah angka kekerasan. Terbukti bahwa terjadi peningkatan angka kekerasan lapisan akibat proses post-treatment.

Penambahan waktu post-treatment menyebabkan kenaikan angka kekerasan lapisan nitridasi dari $145 \mathrm{VHN}$ naik menjadi 169,2 VHN yang didapatkan pada waktu posttreatment 30 menit.

Kenaikan angka kekerasan di dalam proses post-treatmentdisebabkan karena benturan gas-gaspost-treatment pada permukaan lapisan nitridasi.

\section{Saran}

Diperlukan adanya penelitian lebih lanjut terkait penambahan waktu posttreatment sehingga dapat lebih diketahui perubahan angka kekerasan. Variasi tekanan pelapisan juga perlu ditambahkan guna mendapatkan perbandingan parameter pelapisan yang optimal. Karakterisasi lapisan nitridasi dapat ditambahkan berupa pengujian fatik, sehingga dapat diketahui apakah proses post-treatmentdapat meningkatkan ketahanan fatik.

Pengamatan lapisan yang terbentuk di permukaan substrat juga perlu dilakukan untuk mengetahui ketebalan lapisan yang terbentuk sehingga dapat dipastikan bahwa terjadi benturan oleh gas-gas post-treatment (efek shot peening). Selain itu, pengujian unsur lapisan juga perlu dilakukan untuk memastikan bahwa lapisan yang terbentuk adalah lapisan nitridasi, dan tidak ada gas argon yang terjebak pada lapisan (tidak multi layers).

\section{Daftar Pustaka}

[1]Suprapto, B. A. T. Sujitno, Taufik, A. Abdussalam, D. Priyantoro, "Analisis Permukaan Material Aluminium Paduan (AlSiCu) Hasil Nitridasi Ion,"Jurnal Iptek Nuklir Ganendra, vol. 19, no. 2, hal. 65-74, Juli 2016.

[2]L. Susita R. M., B. Siswanto, I. Aziz, A. Anggraini H., Sudjatmoko, "Pengaruh Dosis 
Ion Nitrogen Pada Ketahanan Korosi, Struktur Mikro Dan Struktur Fase Biomaterial Stainless Steel Austenitik 316L, "Jurnal Iptek Nuklir Ganendra, vol. 19, no. 1, hal. 47-54, Januari 2016.

[3] S. S. Tzeng, Y. J. Wu, J. S. Hsu, "The effects of plasma pre-treatment and post treatment on diamond-like carbon films synthesized by RF plasma enhanced chemical vapor deposition,"Vacuum, vol. 83, hal. 618-621, 2009.

[4] S. S. Tzeng Y. L. Fang, Y. K. Chih, Y. C. Lin, C. F. Tuan, "Influence of nitrogen plasma posttreatment on diamond-like carbon films synthesized by RF plasma enhanced chemical vapor deposition,"Diamond \& Related Materials, vol. 19, hal. 783-786, 2010.

[5] S. S. Tzeng, Y. L. Fang, Y. K. Chih, Y. G. Hu, J. S. Hsu, C. L. Wu, G. J. Wu, "Surface characterization and nanomechanical properties of diamond-like carbon films synthesized by RF plasma enhanced chemical vapor deposition,"Thin Solid Films, vol. 519, hal. 4870-4873, 2011.

[6] W. Anhar, N. Jamal, Suprapto, "Pengaruh posttreatment plasma CVD lapisan diamond-like carbon terhadap sifat kekerasan permukaan baja AISI 410,"Jurnal Rotor, vol. 10, no. 1, hal. 6266, April 2017.

[7]L. Singh, R. A. Khan, M. L. Aggarwal, "Relationship between damping factor and compressive residual stress for shot peened austenitic stainless steel,"ISRN Mechanical Engineering, hal. 1-7, 2011.

[8]C. Jeon, C. Y. Son, C. P. Kim, S. Lee, "Effect of shot peening on fatigue properties of $\mathrm{Zr}$ based amorphous alloys containing ductile crystalline particles,"Metallurgical and Materials Transactions A, vol. 43A, hal. 471478, Februari 2012.

[9]L. Trsko, "The effect of different shot peening intensities on fatigue life of AW 7075 aluminium alloy,"Materials Engineering, vol. 20, hal. 167-173, 2013.

[10] Y. Fouad, M. E. Metwally, "Shot-peening effect on high cycling fatigue of $\mathrm{Al}-\mathrm{Cu}$ alloy,"Metallurgical and Materials Transactions A, vol. 44A, hal. 5488-5492, Desember 2013. 